\title{
Peat soils stabilization using lime-cement mixture to prevent peat fires
}

\author{
Muhardi $^{1 *}$, Gunawan Wibisono ${ }^{1}$, and Harist Febrie R Z ${ }^{1}$ \\ ${ }^{1}$ Department of Civil Engineering, University of Riau, Pekanbaru, Riau
}

\begin{abstract}
Peat fires in tropical peatland causes significant damage to peatland ecology and the landscape. Peat fires are usually occurred during the regular dry season for agricultural purposes such as oil palm plantation. Peat soils is one of the problematic soils due to its high water content, low shear strength, high organic, low bearing capacity and high compressibility. Because of these problems, improvement method such as compaction and stabilization are important when the peat soils use as a soil foundation. This paper describes laboratory research done on strength for stabilized of peat to evaluate their different physical and mechanical properties mainly compaction, unconfined compressive strength (UCS) and the California bearing ratio (CBR) test. Burning test was also conducted to observe the effect of stabilization of peat soils to prevent peat fires. The stabilizing agents used were $5 \%$ lime $\left(\mathrm{CaCO}_{3}\right)$ and Portland Composite Cement (PCC). Different variation of PCC was used in experiments for the optimum variation. Optimum moisture content was taken $100 \%$ based on the other research. In UCS and CBR test, the highest of strength increase occurred in variations $15 \%$ PCC were equal to $59.44 \%$ and $100.17 \%$ respectively compare than the pure peat soils. While in burning test, stabilized peat soils has a burning point and ash point much longer time to start burning and completely become ash than pure peat soils. Stabilized peat soils can increase the burning process time and not easy to fire.
\end{abstract}

\section{Introduction}

Peat fires in tropical peatland cause significant damage to peatland ecology and the landscape. Peat fires usually occur during the regular dry season for agricultural purposes such as oil palm plantation. Peat soils are one of the problematic soils due to its high water content, low shear strength, high organic, low bearing capacity, and high compressibility. Because of these problems, improvement method such as compaction and stabilization are essential when the peat soils use as a soil foundation. Approximately 3,867,413 hectares or $60.08 \%$ of peatlands is located in Riau Province [1]. In the last few years burning the peatland considered the fastest and economically way for clearing the peatland. In Malaysia, peatland fires are not so severe as in Indonesia. This is because the peat layer is compacted using the heavy equipment before utilizing peatland. This compaction causes voids or pores peat soil becomes less, and so the fire does not spread, compaction also

\footnotetext{
* Corresponding author: muhardi@eng.unri.ac.id
} 
increases the weight of dry soil [2]. Many factors can affect the stabilization methods. According to Yulianto et al. [3], a thick layer of peat, a type of peat soil and the amount of compression, the kind of agent stabilized were the factors of peat soil stabilization methods. Huat and Maail [4] showed that the addition of cement and lime with a percentage of 5$15 \%$ and $5-25 \%$ of the dry weight of the soil, can improve the properties of these soils. In Riau itself, there is no action for compacting or stabilization in the handling of peatland. This paper describes laboratory research done on strength for stabilized of peat to evaluate their different physical and mechanical properties. Burning test was also conducted to observe the effect of stabilization of peat soils to prevent peat fires.

Research that conducted by Hadijah in Ilyas et al. [5] and Octriyana [6] that the optimum water content for compaction is between $100 \%$ and $160 \%$ based on the compaction curve. Nugroho [7] tested the burning characteristics (self-ignition) of some material that is peat, coco oil, wood chips and bituminous coals that showed in Fig. 1. Nugroho tested by raising the oven temperature increased gradually. From the test results obtained critical oven temperature $=171 \pm 6^{\circ} \mathrm{C}$ for peat. It is also showed that the high water content which is the peat taken a long time to evaporate that indicated by the length of temperature $60-70^{\circ}$ in the period. The release of water content, temperature rise, until the burned (of smoke) is a phenomenon of spontaneous the burned.

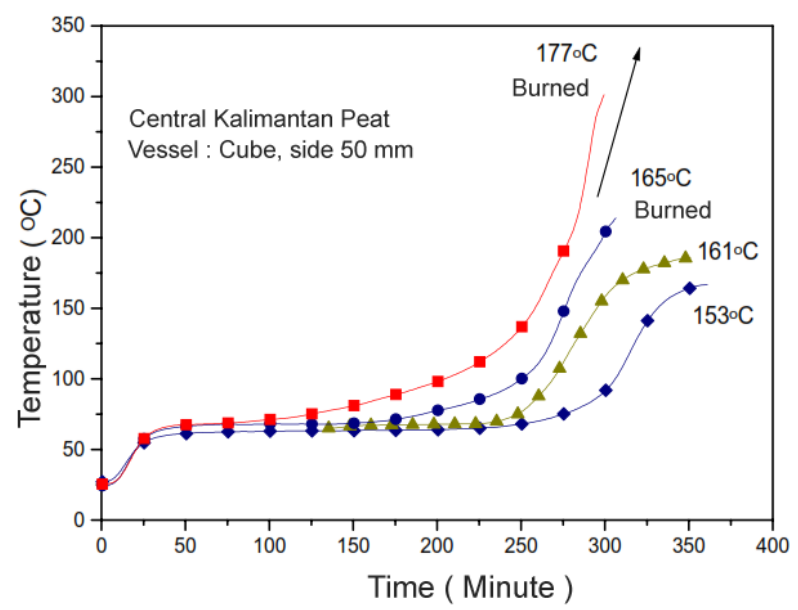

Fig.1. Temperature measurement results for peat soils.

\section{Research methodology}

The study was conducted at the Laboratory of Soil Mechanics the Faculty of Engineering, University of Riau. Physical and mechanical properties mainly standard Proctor compaction, unconfined compressive strength (UCS) and the California bearing ratio (CBR) test are conducted. Burning test was also done to observe the effect of stabilization of peat soils to prevent peat fires. The stabilizing agents used were $5 \%$ lime $\left(\mathrm{CaCO}_{3}\right)$ and Portland Composite Cement (PCC). A different variation of PCC (5\%, 10\%, and 15\%) was used in experiments for the optimum variation. Optimum moisture content was taken $100 \%$ based on the other research. The peat soil was taken from Rimbo Panjang, Kampar, Riau. Physical properties of peat soil, $\mathrm{PCC}$ and $\mathrm{CaCO}_{3}$ were also conducted in the Laboratory. 


\section{Results and discusssion}

Test results of Rimbo Panjang peat soil characteristics are shown in Table 1. According to ASTM D 4427 [8] the peat soil of Rimbo Panjang, classified as Low Ash because has the ash content of $0.77 \%$, Saptic because has the fiber content of $28.82 \%$ and slightly Absorbent because it has a natural water content of $269.11 \%$. Test results of PCC Cement and $\mathrm{CaCo}_{3}$ lime characteristics are shown in Table 2 and Table 3, respectively.

Table 1. Characteristics of Rimbo Panjang peat soil.

\begin{tabular}{|c|c|}
\hline Test & Value \\
\hline Natural water content $(w), \%$ & 269.11 \\
\hline Specific Gravity (Gs) & 1.36 \\
\hline Unit Weight $(\mathrm{\gamma}), \mathrm{kN} / \mathrm{m}^{3}$ & 7.98 \\
\hline Dry Unit Weight $\left(\mathrm{Xd}_{\mathrm{d}}\right), \mathrm{kN} / \mathrm{m}^{3}$ & 2.14 \\
\hline Ash content, $\%$ & 0.77 \\
\hline Organic content, $\%$ & 99.23 \\
\hline Fiber Content, \% & 28.82 \\
\hline
\end{tabular}

Table 2. Test results of PCC characteristics.

\begin{tabular}{|c|c|}
\hline Test & Value \\
\hline Water content $(w) \%$ & 0.12 \\
\hline Specific Gravity $(\mathrm{Gs})$ & 2.92 \\
\hline
\end{tabular}

Table 3. Test results of $\mathrm{CaCO}_{3}$ characteristics.

\begin{tabular}{|c|c|}
\hline Test & Value \\
\hline Water content $(w) \%$ & 0.42 \\
\hline Specific Gravity (Gs) & 2.7 \\
\hline
\end{tabular}

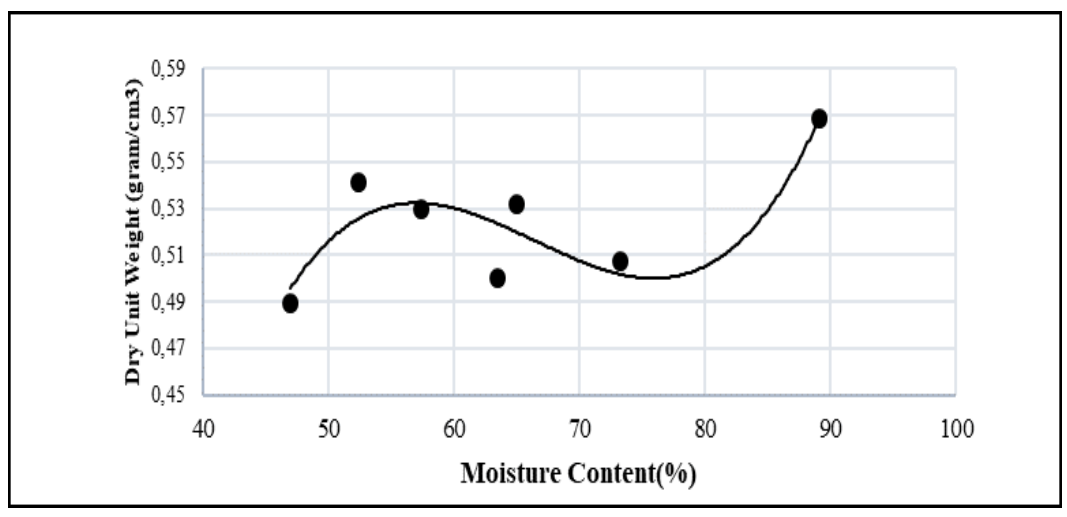

Fig. 2. Result of standard Proctor test. 
The result of the standard Proctor test is shown in Fig. 2. From the test results showed graph has one and a half peak. Therefore, it can not be used to determine optimum moisture content (OMC). Thus, the water content of $100 \%$ is chosen as OMC in the next test, based on the other research $[5,6]$.

Unconfined Compressive (UC) testing conducted to determine the shear strength of each of the various samples using OMC value of $100 \%$. UC testing results can be seen in Table 4 and Fig. 3, respectively.

Table 4. Result of UC test.

\begin{tabular}{|c|c|c|c|}
\hline Description & $\mathbf{q u}_{\mathbf{u}}(\mathbf{k P a})$ & $\mathbf{c}_{\mathbf{u}}(\mathbf{k P a})$ & $\begin{array}{c}\text { Percentage increase in } \mathbf{q u}_{\mathbf{u}} \\
\text { value (\%) }\end{array}$ \\
\hline Pure Ppat & 79.52 & 39.76 & 0 \\
\hline Peat $+5 \% \mathrm{CaCO}_{3}+5 \%$ PCC & 87.35 & 43.67 & 9.85 \\
\hline Peat $+5 \% \mathrm{CaCO}_{3}+10 \%$ PCC & 105.00 & 52.50 & 32.04 \\
\hline Peat $+5 \% \mathrm{CaCO}_{3}+15 \%$ PCC & 126.79 & 63.39 & 59.44 \\
\hline
\end{tabular}

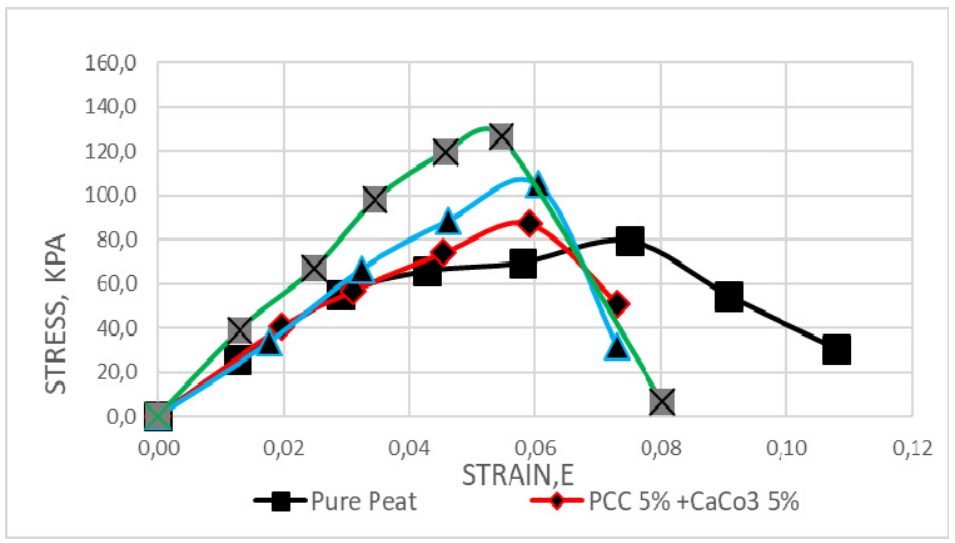

Fig. 4. Graph of UC test.

From the result in Table 4 shows that qu (unconfined compressive strength) and cu (cohesion undrained) of peat increase when PCC percentage increase. The highest of qu was obtained in PCC percentage of $15 \%$ that equal to $126.79 \mathrm{kPa}$ in which percentage of increase was 59.44\% compared than pure peat. It can be seen from Fig. 4 that the stressstrain curve showed the peat soil mixture becomes slightly brittle due to PCC percentage increase.

Table 5. Results of CBR test.

\begin{tabular}{|c|c|c|}
\hline Description & CBR (\%) & Percentage increase in CBR value (\%) \\
\hline Pure peat & 5.99 & 0 \\
\hline Peat $+5 \% \mathrm{CaCO}_{3}+5 \%$ PCC & 9.74 & 62.60 \\
\hline Peat $+5 \% \mathrm{CaCO}_{3}+10 \%$ PCC & 10.99 & 83.47 \\
\hline Peat $+5 \% \mathrm{CaCO}_{3}+15 \%$ PCC & 11.99 & 100.17 \\
\hline
\end{tabular}


CBR test is performed to determine the bearing capacity of the soil. CBR testing results are shown in Table 5. Variations of peat soil mixture (lime and PCC) affect the bearing capacity of each sample. In Table 5 shows that a variation of 5\% lime $+15 \%$ PCC has the highest of CBR in which percentage of increase was $100.17 \%$ compare than the pure peat.

There are three stages in the burning test:

1. The stage of evaporation. Evaporation stage is characterized by the change in the color of peat from black to brown. The fire reduced soil moisture and water from the soil to evaporate. It can be seen in Fig. 5 and Fig. 6.

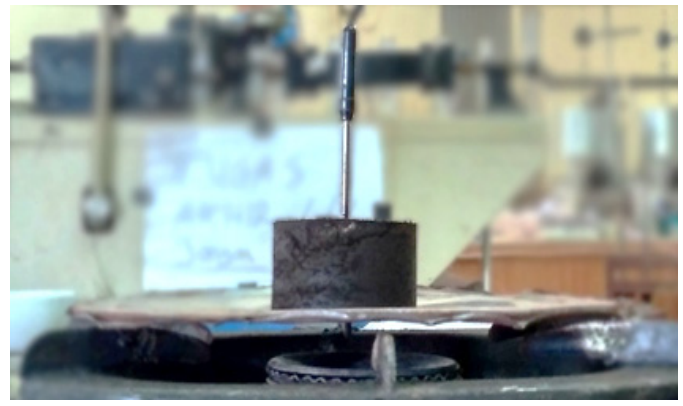

Fig. 5. Sample before burning test.

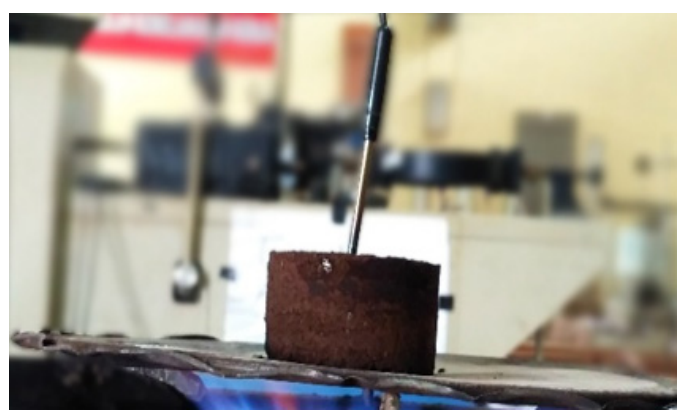

Fig. 6. Evaporation stage changed soil to brown.

2. The stage of burning point. This stage was characterized by the appearance of the first hot spot. Fire spreaded from the bottom up to the top. Each sample variation has hot spot at different temperature and time that it can be seen in Table 6. The appearance of the fire can be seen in Fig. 7 .

Table 6. Burning point temperature and time.

\begin{tabular}{|c|c|c|}
\hline Sample variation & $\begin{array}{c}\text { Burning point } \\
\text { temperature }\left({ }^{0} \mathbf{C}\right)\end{array}$ & Time (minutes) \\
\hline Uncompacted peat & 45 & 1 \\
\hline Compacted peat & 72 & 4 \\
\hline Peat $+5 \% \mathrm{CaCO}_{3}+5 \%$ PCC & 94 & 23 \\
\hline Peat $+5 \% \mathrm{CaCO}_{3}+10 \%$ PCC & 94 & 22 \\
\hline Peat $+5 \% \mathrm{CaCO}_{3}+15 \%$ PCC & 94 & 24 \\
\hline
\end{tabular}




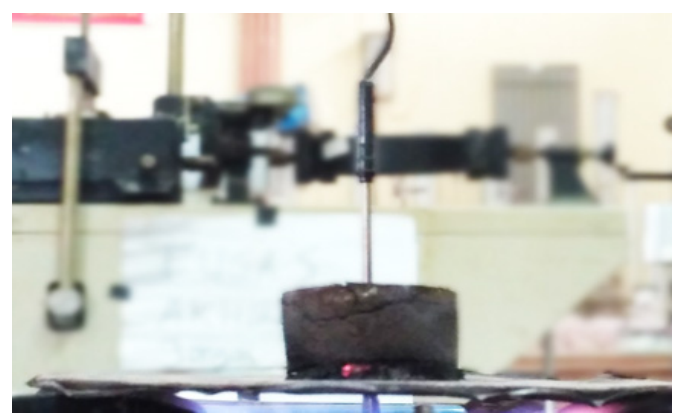

Fig. 7. Burning point, marked with the appearance of fire hot spot.

3. The stage of the ash. At this stage was marked by the changing the soil into ashes, however there was still fire in the bottom. Each variation has a point ash at different temperature and time that it can be seen in Table 7. Ash of peat soil mixture can be seen in Fig. 8.

Table 7. Ash point temperature and time.

\begin{tabular}{|c|c|c|}
\hline Sample variation & Ash point temperature $\left({ }^{\circ} \mathbf{C}\right)$ & Time (minutes) \\
\hline Uncompacted peat & 165 & 15 \\
\hline Compacted peat & 190 & 32 \\
\hline Peat $+5 \% \mathrm{CaCO}_{3}+5 \%$ PCC & 200 & 50 \\
\hline Peat $+5 \% \mathrm{CaCO}_{3}+10 \%$ PCC & 200 & 55 \\
\hline Peat $+5 \% \mathrm{CaCO}_{3}+15 \%$ PCC & 200 & 63 \\
\hline
\end{tabular}

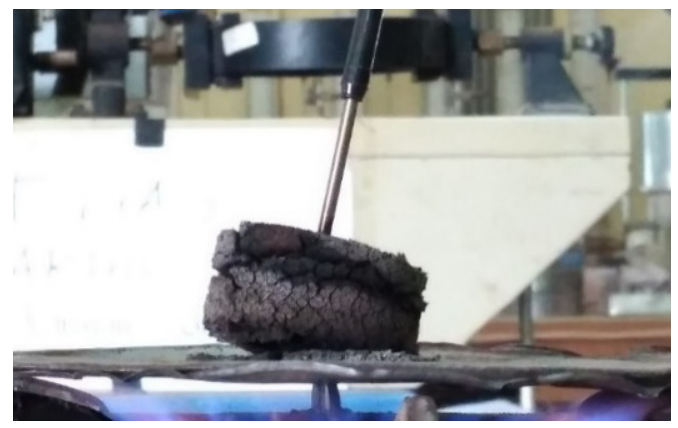

Fig. 8. Ash of peat soil mixture.

Stabilization of peat soil with a mixture of PCC and lime shows the burning process has much longer than the original peat soil (not compacted). This is due to the addition of the mixture will fill voids of the peat soil. Uncompacted peat soil was faster to burn due to air in voids of peat soil that made the burning process in 15 minutes. The process of compaction and stabilization can delay the burning for compacted peat in 32 minutes, the first variation (Peat $+5 \% \mathrm{CaCO}_{3}+5 \%$ PCC) was 50 minutes, and the second variation $\left(\right.$ Peat $+5 \% \mathrm{CaCO}_{3}+10 \%$ PCC) and the third variation (Peat $\left.+5 \%+15 \% \mathrm{CaCO}_{3}+\mathrm{PCC}\right)$ was 55 and 63 minutes, respectively.

From the tests performed by Nugroho [7], the long temperature period occurs at 60$70^{\circ} \mathrm{C}$ for peat soil with high moisture content, whereas for compacted peat in this study was 
of $90-100^{\circ} \mathrm{C}$ in 5 minutes. Compared by the variation, a long temperature period occurred at $90-100{ }^{\circ} \mathrm{C}$ Mixture of Peat $+5 \% \mathrm{CaCO}_{3}+5 \% \mathrm{PCC}$ has 15 minutes. Peat $+5 \% \mathrm{CaCO}_{3}+$ $10 \%$ PCC was 16 minutes, and Peat $+5 \% \mathrm{CaCO}_{3}+15 \%$ PCC was 24 minutes. Nugroho [7] showed that the burning process considered by the appearance of smoke in which evaporation stage occurred for this study. This is due to the difficulty in determining the result of evaporation vapors and smoke from burning.

In this study, when the temperature exceeds $440^{\circ} \mathrm{C}$ showed only remaining white ash. It is the same as that revealed by Sa'don et al. [9], where the temperature exceeds $440^{\circ} \mathrm{C}$ organic material burned. In this study, the temperature reached $440^{\circ} \mathrm{C}$ takes time 63 for compacted peat soil. Compacted peat soil completely turned into ashes at a temperature of $525^{\circ} \mathrm{C}$ for 66 minutes. As for the variation, the temperature reached $440^{\circ} \mathrm{C}$ at 62 minutes for Peat $+5 \%$ PCC $+5 \% \mathrm{CaCO}_{3}$ and entirely to ash at a temperature of $617^{\circ} \mathrm{C}$ at 72 minutes. For Peat $+10 \% \mathrm{PCC}+5 \% \mathrm{CaCO}_{3}$ temperature of $440^{\circ} \mathrm{C}$ was at 68 minutes and entirely reduced to ashes at $606^{\circ} \mathrm{C}$ at 84 minutes. Peat $+15 \%$ PCC $+5 \% \mathrm{CaCO}_{3}$ reached a temperature of $440^{\circ} \mathrm{C}$ for 74 minutes and reduced to completely ash at a temperature of $598^{\circ} \mathrm{C}$ for 85 minutes. For more detail can be seen in Table 8 .

Table 8. Relationship between temperature period and time.

\begin{tabular}{|c|c|c|c|c|}
\hline \multirow[b]{2}{*}{ Sample variation } & \multirow[b]{2}{*}{$\begin{array}{c}\text { Period } \\
\text { (minutes) }\end{array}$} & \multirow{2}{*}{$\begin{array}{c}\text { Reaches a } \\
\text { temperature } \\
\text { of } 440^{\circ} \mathrm{C} \\
\text { (minutes) }\end{array}$} & \multicolumn{2}{|c|}{ Fully ashes } \\
\hline & & & $\begin{array}{c}\text { Temperature } \\
\left({ }^{\circ} \mathrm{C}\right)\end{array}$ & $\begin{array}{c}\text { Time } \\
\text { (minutes) }\end{array}$ \\
\hline Uncompacted peat & 4 & 26 & 610 & 28 \\
\hline Compacted peat & 5 & 63 & 525 & 66 \\
\hline Peat $+5 \% \mathrm{CaCO}_{3}+5 \% \mathrm{PCC}$ & 15 & 62 & 617 & 72 \\
\hline Peat $+5 \% \mathrm{CaCO}_{3}+10 \%$ PCC & 16 & 68 & 606 & 84 \\
\hline Peat $+5 \% \mathrm{CaCO}_{3}+15 \%$ PCC & 24 & 74 & 598 & 85 \\
\hline
\end{tabular}

\section{Conclusions}

Based from this study it can be concluded some points as follows. Based on ASTM D4427 the Rimbo Panjang peat soil classified as low ash, Sapric, and slightly absorbent. From the results obtained proctor compaction test, the curve has one and a half peak. The addition of PCC and $\mathrm{CaCO}_{3}$ in peat soil showed an increase of UCS and CBR compare than the pure peat soil. In the burning test, pure peat soil has a point of fire burning at a temperature of $72^{\circ} \mathrm{C}$ in 2 minutes. Meanwhile, the ash point appeared when the temperature was $190^{\circ} \mathrm{C}$ in 33 minutes. Pure peat soils completely turned into ashes at a temperature of $525^{\circ} \mathrm{C}$ in 66 minutes. Variation of peat soil mixture have burning point almost the same at $94^{\circ} \mathrm{C}$ at 22 to 24 minutes. While the ash point, occurred at the same temperature of $200^{\circ} \mathrm{C}$ at 50 to 63 minutes. Variation of Peat $+5 \% \mathrm{CaCO}_{3}+5 \% \mathrm{PCC}$ was completed to ash at a temperature of $617^{\circ} \mathrm{C}$ at 72 minutes. Peat $+5 \% \mathrm{CaCO}_{3}+10 \% \mathrm{PCC}$ was $606^{\circ} \mathrm{C}$ at 84 minutes. For the last variation was $598^{\circ} \mathrm{C}$ for 85 minutes. In the burning process for compacted peat soil, the long temperature period occured at $90-100^{\circ} \mathrm{C}$ for 5 minutes, while for variation takes time between 15 minutes to 24 minutes. The addition of $\mathrm{CaCO}_{3}$ and $\mathrm{PCC}$ would delay burning process. 


\section{References}

1. Anonim. Peta lahan gambut Indonesia (Badan Penelitian dan Pengembangan Pertanian, Peta Lahan Gambut Indonesia, 2011)

2. Juft, Mengapa jarang terjadi kebakaran hutan dan kebun sawit di Malaysia. At: https://www.konfrontasi.com/content/politik/mengapa-jarang-terjadi kebakaran-hutandan-kebun-sawit-di-malaysia (2016).

3. F. Yulianto, N.E. Mochtar, F.E. Harwadi, Proc. of the First Makassar International Conference on Civil Engineering (MICCE2010) (2015)

4. B.B.K. Huat, S. Maail, T.A. Mohamed. American J. of Appl. Sci. 2, 7 (2005)

5. T. Ilyas, W. Rahayu, D.S. Arifin. J. Teknologi 21, 1-8 (2008)

6. R. Octriyana, Compresibility behavior of compacted peat soil using modified Proctor (Universitas Indonesia, Jakarta, 2010)

7. Y.S. Nugroho, Makara J. of Tech. 6 (2002)

8. ASTM, Annual Book of ASTM Standards Volume 0408 Soil and Rock (ASTM, Philadelphia, 2010)

9. N.M. Sa'don, A.R.A. Karim, W. Jaol, W.H.W. Lili, J. of Civil Eng. Sci. and Tech. 5, 3 (2014) 